\title{
Behind the Scenes: Establishing a Scriptorium in the Eleventh-Century Monastery of Saint-Sépulcre, Cambrai
}

\author{
Tjamke Snijders
}

7 me monastery of Saint-Sépulcre, located in the city of Cambrai in northern France, was founded in 1064. Its first generation of monks included a man who called himself Fulbert the Sinner, "Fulbertus Peccator." He was a seasoned scribe who oversaw the establishment of Saint-Sépulcre's scriptorium. He was also a proud man, who left his "signature" by means of a colophon in several manuscripts on which he

* This article was written at KU Leuven, KU Leuven Libraries, Special Collections, Mgr. Ladeuzestraat 21, B-30oo Leuven, Belgium; and at Ghent University with the support of the Research Foundation-Flanders (FWO).

\begin{abstract}
Little work has thoroughly examined the problems that faced startup scriptoria in the High Middle Ages. This article examines the scriptorium of Saint-Sépulcre in the first decades after this Cambrai monastery was founded in 1064. A man who called himself Fulbertus Peccator ("Fulbert the Sinner") led the scriptorium during those years. He wrote at least 1,100 folios of foundational texts, but could not single-handedly fill the entire library. Fulbert therefore encouraged most, if not all, of Saint-Sépulcre's monks to participate in the production of hagiographical manuscripts, even if those monks were wholly unqualified. This article demonstrates that Fulbert's unusual decision not only helped fill the library with the hagiographical texts it needed, but also changed the significance of the resulting manuscripts for the monastic community. Much more than the sum of their parts, these manuscripts were created as objects that represented the communal spirit and the vibrancy of the newly founded monastery of Saint-Sépulcre.
\end{abstract}

Keywords: Fulbertus Peccator, Fulbert the Sinner, Cambrai, Saint-Sépulcre, Scriptoria, Hagiography, Paleography

Manuscripta 63.1 (2019) : DOI 


\section{Tjamke Snijders}

worked. ${ }^{1}$ This habit allows us to reconstruct his scribal output and to analyze many decisions that were made in

2 Saint-Sépulcre's fledgling scriptorium: which texts were copied and which were ignored, what kinds of manuscripts were delegated to relatively untrained scribes, and which organizational principles were adhered to. Fulbert's colophons reveal how he established and organized a scriptorium in Saint-Sépulcre.

The presence of these colophons also allows us to understand how these manuscripts acquired symbolic meaning at their moment of production. Of course, manuscripts had meaning because they were gathering places for texts, and these texts were meaningful in and of themselves. However, manuscripts also acquired meaning because, as objects, they embodied the creativity, the skill, and the associational value of the scribe(s) and/or illuminator(s) who worked on them. ${ }^{2}$ A text that was physically written by the abbot of a monastery surely had a different meaning for the community than a text that was laboriously copied out by a young novice, not because the words were different, but because the text embodied some of the status and skills of its scribe. Put differently, manuscripts acquired symbolic significance partly from the circumstances and the people that produced them. This article shows how Fulbert's organization of a new scriptorium influenced the significance of the manuscripts that were created there.

1. The most recent study of Saint-Sépulcre's scriptorium is Denis Muzerelle, Manuscrits datés des bibliothèques de France, vol. 1, Cambrai (Paris, 200o), xxii-xxv. On the colophons of Fulbert, see Bénédictins du Bouveret, Colophons de manuscrits occidentaux des origines au XVIe siècle (Fribourg, 1965-82), 2:133, nos. 4607-4609.

2. Karen L. Jolly, "Dismembering and Reconstructing Ms Durham, Cathedral Library, A.IV.19," in Scraped, Stroked, and Bound: Materially Engaged Readings of Medieval Manuscripts, ed. Jonathan Wilcox (Turnhout, 2013), 177-200 at 198-99. 


\section{FULBERT THE SINNER}

The early history of Saint-Sépulcre has never been the subject of much research. ${ }^{3}$ According to one eighteenth-century manuscript, its foundations were laid in 1047, when an epidemic swept through Cambrai and there were just too many bodies to bury. ${ }^{4}$ Bishop Gerard I founded a small church near the city walls to bury the poor and the strangers in the name of the Holy Sepulchre. In 1064 his successor Lietbertus constructed a monastery next to the church, dedicating it to Christ and his Holy Sepulchre, his Holy Mother, and all God's Saints, and assigned an abbot and some monks to the new location. A bright light appeared in the heavens, and twenty-two bodies of saints were gathered to celebrate the foundation of Saint-Sépulcre. ${ }^{5}$

3. Notwithstanding, there are no fewer than 1,421 (mostly) unstudied documents from Saint-Sépulcre's archives awaiting their historian in the Archives départementales du Nord in Lille, France (série $3 \mathrm{H}$ ). Even though most materials postdate the thirteenth century, there are some eleventh-and twelfth century items of interest, including $3 \mathrm{H}_{2} / 5$ (the oldest pontifical privileges); $3 \mathrm{H}_{5} 6$ (donations); $3 \mathrm{H}_{73}$ (local conflict); $3 \mathrm{H}_{188}$, 200, and 209 (property); $3 \mathrm{H}_{2} 55-3 \mathrm{H} 257$ (sixteenth-century cartularies); ${ }_{3} \mathrm{H}_{2} 62$ (a nineteenth-century copy of the Chronologia stemmatica).

4. Chronologia stemmatica beati fundatoris et abbatum ecclesiae ac monasterii Sancti Sepulchri Cameracensis, ordinis Sancti Benedicti cum brevi expositione vitae, gestorum et praeminentiarum eorumdem ex actis authenticis in eodem monasterio asservatis collecta anno 1740, in Douai, Bibliothèque Marceline Desbordes-Valmore, MS 899. A virulent epidemic indeed decimated Flanders in 1046 and Hainaut in 1056 according to Lodewyk Torfs, Fastes des calamités publiques survenues dans les Pays-Bas et particulièrement en Belgique, depuis les temps les plus reculés jusqu'a nos jours (Paris and Tournai, 1859), 17.

5. See also Alphonse Wauters et al., eds., Table chronologique des chartes et diplômes imprimés concernant l'histoire de la Belgique, 11 vols. (Brussels, 1866-1912) 1:515; Diplomata belgica: Les sources diplomatiques des Pays-Bas méridionaux au Moyen Âge = The Diplomatic Sources from the Medieval Southern Low Countries, no. 3824, http://www.diplomata-belgica.be/charter_details_fr.php?dibe_id=3824. 


\section{Tjamke Snijders}

At the time of the monastery's foundation, the diocese of Cambrai was under intense pressure. Cambrai was subser4 vient to the Holy Roman Empire in worldly matters and adhered to the Pope in spiritual matters. This duality became problematic when in 1056 the six-year-old Henry IV was elected King of the Romans and the ensuing political struggles between the Empire and the Pope profoundly affected Cambrai. Around 1093 the diocese was split into one part that shed its imperial connections (Arras) and another that maintained its attachment to the Empire (and retained the name of Cambrai). ${ }^{6}$ These tensions forced newly founded Saint-Sépulcre to tread carefully regarding the religious and political statements it made.

For the first decades of its existence, Saint-Sépulcre was a small and relatively poor abbey. Bishop Lietbertus tried to look out for his foundation, providing it with the relics of local saints as well as with goods and privileges. 7 In 1075 he asked Pope Gregory VII to take the abbey under his protec-

6. Bernard Delmaire, Le diocèse d'Arras de 1093 au milieu du XIVe siècle: Recherches sur la vie religieuse dans le nord de la France au Moyen Âge (Arras, 1994), 163-64, 203-4, 402; Maurice Chartier, "Cambrai (diocèse)," in Dictionnaire d'histoire et de géographie ecclésiastique, ed. Alfred Baudrillart et al., 32 vols. to date (Paris, 1912-) 11:547-65; Irven M. Resnick, "Odo of Cambrai and the Investiture Crisis in the Early Twelfth Century," Viator 28 (1997): 83-98; and John S. Ott, Bishops, Authority, and Community in Northwestern Europe, c. 1050-1150, Cambridge Studies in Medieval Life and Thought, 4th ser., 102 (Cambridge, 2015), 197221 ("Sanctity and History in a Border Diocese: The Vita of Lietbert of Cambrai [1051-76]").

7. For the early history of Saint-Sépulcre, see Rudolf of Saint-Sépulcre, "Vita Lietberti episcopi Cameracensis auctore Rudulfo monacho S. Sepulchri Cameracensis," ed. Adolphus Hofmeister, in Monumenta Germaniae historica ... Scriptores, vol. 30.2 (Leipzig,1934), 838-68 at 859-61 and 866-68; "Gesta episcoporum Cameracensium," ed. Lud. C. Bethmann, in Monumenta Germaniae historica ... Scriptores, vol. 7, ed. Georg Heinrich Pertz (Hannover, 1846; repr. Leipzig, 1925), 402-525 at 496-97; and the Chronologia stemmatica. 
tion. ${ }^{8}$ One year later, Bishop Lietbertus was succeeded by Gerard II (1076-92) who confirmed his predecessor's donations to "Abbot Walter and the ten poor monks" who lived in Saint-Sépulcre in 1079. ${ }^{9}$ Contemporary historical sources do not pay Saint-Sépulcre much notice. ${ }^{10}$ The monastery was obviously struggling.

Nevertheless, Saint-Sépulcre diverted very significant resources into manuscript production. No less than thirteen manuscripts have been preserved from the period between 1076 and 1092, and the monks likely produced many more. Five of these manuscripts were signed with the vainly modest phrase "I entreat everyone who reads this to remember Fulbert the Sinner (and Scribe)." The phrasing varies slightly from manuscript to manuscript, but the scribe always identified himself as "Fulbertus Peccator." ${ }^{11}$ Seven more unsigned manuscripts also contain fragments of texts that were written by Fulbert, who was thus actively involved in twelve of the thirteen manuscripts preserved from this

8. Lille, Archives départementales du Nord, $3 \mathrm{H}_{2} / 5$, edited in Quellen und Forschungen zum Urkunden- und Kanzleiwesen Papst Gregors VII, ed. Leo Santifaller, Studi e testi 190 (Vatican City, 1957), 86-88.

9. Notitia ecclesiarum Belgii, ed. Aubert le Mire (Antwerp, 1630), 206; see also Erik Van Mingroot, "Gérard II de Lessines," in Dictionnaire d'histoire et de géographie ecclésiastique, 20:751-55.

10. See, for example, Raoul de Saint-Trond, Gesta abbatum Trudonensium I-VII, ed. Paul Tombeur, Corpus christianorum, Continuatio mediaevalis 257 (Turnhout, 2013); Steven Vanderputten, "Compilation et réinvention à la fin du douzième siècle: Andre de Marchiennes, le Chronicon Marchianense et l'histoire primitive d'une abbaye bénédictine (édition et critique des sources)," Sacris erudiri 42 (2003): 403-36; Folcuin, "Gesta abbatum Lobiensium," in Monumenta Germaniae historica ... Scriptores, vol. 7, 52-74, and Folcuin, "Gesta abbatum Sithiensium," ed. O. Holder-Egger, in Monumenta Germaniae historica ... Scriptores, vol. 13 (Hannover, 1881; repr. Leipzig, 1925), 607-35; and the Gesta episcoporum Cameracensium.

11. Muzerelle, Manuscrits datés ... Cambrai, xxii. See Cambrai, Bibliothèque municipale (also known as the Médiathèque d'Agglomération de Cambrai), MSS 215, 217, 218, 247, and 819. 


\section{Tjamke Snijders}

period. ${ }^{12}$ One of these has been dated with relative accuracy. Cambrai, Bibliothèque municipale, MS 864, fol. $125 \mathrm{~V}$ con-

6 tains a list of the bishops of Cambrai that was continued in the original hand up to Bishop Gerard II (1076-92)..$^{13}$ This list thus places the production of Cambrai 864 in the years between 1076 and 1092 and by extension dates all thirteen manuscripts to that approximate period.

Who was this Fulbert the Sinner? As already indicated, he appears to have possessed a strong sense of his own importance, seeing fit to leave his name on several of the manuscripts he produced. ${ }^{14} \mathrm{He}$ put his name in very conspicuous places, such as the title page of Cambrai 215, where he signed his name in bold red ink (fol. rr):

\section{PRIMA PARS IN IOB}

Liber sancti Sepulchri Cameracensis.

Si quis abstulerit, anathema sit.

Servanti benedictio, tollenti maledictio.

Amen, amen, amen, amen.

Obsecro quicumque hęc legeris, ut Fulberti scriptoris et peccatoris memineris.

Denis Muzerelle speculates that Fulbert may have been a lay scribe because he refers to himself as scriptor and peccator, but never as frater, monachus, diaconus, or presbyter. On the other hand, Muzerelle also notes that the "Fulbertus c[onversus] et mo[nachus]" who is inscribed in

12. Cambrai, Bibliothèque municipale, MSS 216, 219, 504, 807, 846, 863 , and 864. Cambrai, Bibliothèque municipale, MS 506 does not contain interventions by Fulbert, but several of the hands from Cambrai 846, 863, and 864 are present, thus dating it to roughly the same period.

13. Muzerelle, Manuscrits datés ... Cambrai, 102-3.

14. Richard Gameson, "'Signed' Manuscripts from Early Romanesque Flanders: Saint-Bertin and Saint-Vaast," in Pen in Hand: Medieval Scribal Portraits, Colophons and Tools, ed. Michael Gullick (Walkern, UK, 2006), $31-73$ at 31 . 
Saint-Sépulcre's necrologium on December 31 could well be Fulbert the Sinner. ${ }^{15}$ Lay or monk, Fulbert was not shy about signing his name, and he remained the only person to do so in the scriptorium of Saint-Sépulcre for at least a century. ${ }^{16}$ He was without any doubt the monastery's most important scribe and saw himself as a person whose name was worthy to be remembered in a manuscript context.

There may be an indication of Fulbert's identity in the opening lines of the Vita secunda Aichardi in Cambrai 864. Saint Aichardus (also called Aychadrus) was one of the founding abbots of the Abbey of Jumièges in the late seventh century. In the ninth century a monk from Jumièges first wrote the Vita prima Aichardi, which was rewritten later in the tenth or eleventh century as the Vita secunda Aichardi with the avowed purpose of improving its inane style. ${ }^{17}$ The rewriter begins his work with the words "I, Fulbert the Sinner, salute the gentlemen of the monastery of Jumièges, that is to say, its most holy brothers" (Dominis suis Gimmetiensis coenobii scilicet fratribus sanctissimis, Fulbertus Peccator salutem). In most manuscripts, this salutation is removed because it was neither written by a famous author nor relevant to the contents of the Vita, but the Saint-Sépulcre scribe conscientiously copied it out and even colored the name of "Fulbertus Peccator" with red ink to underline its importance. ${ }^{18}$ Could it be that the Fulbert

15. Muzerelle, Manuscrits datés ... Cambrai, xxii-iii.

16. An exception to this is a certain Lanvinus, who wrote Cambrai, Bibliothèque municipale, MS 544. See Muzerelle, Manuscrits datés ... Cambrai, xxiii.

17. Bibliotheca hagiographica latina [hereafter cited as $B H L$ ], Subsidia hagiographica 6 (Bruxelles, 1898-99; repr. 1992), 30-31, nos. 181 and 182 respectively.

18. Valenciennes, Bibliothèque municipale, MS 514, fol. 78r (SaintAmand-les-Eaux, ca. 1165), and Douai, Bibliothèque Marceline Desbordes-Valmore, MSS 867, fol. 49r (Marchiennes, ca. 1050-75), and 836, fol. 179r (Marchiennes, ca. 1175-1200). 


\section{Tjamke Snijders}

the Sinner who rewrote the Life of Abbot Aichardus was the same man who led the scriptorium of Saint-Sépulcre?

Unfortunately, the identity of Fulbert the Author is uncertain, and even the century in which he worked is open to debate. Felice Lifshitz and John Howe have argued that the terminus post quem for the Vita secunda is the reign of Abbot Anno of Jumièges (940/42-973). During his abbacy, the monks of Jumièges produced a luxurious manuscript about Saint Aichardus that still featured the Vita prima, which indicates that the Vita secunda had not yet been written. ${ }^{19}$ The terminus ante quem for the Vita secunda is provided by the three earliest surviving manuscripts: Rouen, Bibliothèque municipale, MS 1409 (Y.189) from Jumièges (which Lifshitz thought was produced shortly before 1037, but has been more convincingly dated to ca. 1078-95 and is written in a hand similar to that of Cambrai 864); ${ }^{20}$ Oxford, Bodleian Library, MS Bodley 852 (2611), which Howe places in Jumièges and dates to the 1070s; ;1 and Cambrai 864 (107692). The Vita secunda Aichardi must thus have been produced between $940 / 42$ at the earliest, and the 1070s at the latest.

Judging from the preserved codices, the Vita prima Aichardi was popular from the tenth century until sometime

19. John Howe, "The Hagiography of Jumièges (Province of Haute-Normandie)," in L'hagiographie du haut moyen âge en Gaule du Nord: Manuscrits, textes et centres de production, ed. Martin Heinzelmann (Stuttgart, 2001), 91-126 at 106; Felice Lifschitz, The Norman Conquest of Pious Neustria: Historiographic Discourse and Saintly Relics, 684-1090 (Toronto, 1995), 123, and 134n87.

20. Howe, "Hagiography of Jumièges," 101-2; Monique-Cécile Garand, Geneviève Grand, and Denis Muzerelle, Ouest de la France et pays de Loire, vol. 7 of Catalogue des manuscrits en écriture latine portant des indications de date, de lieu ou de copiste, ed. Charles Samaran and Robert Marical, 2 vols. (Paris, 1984), 1:331 and pl. 27.

21. Howe, "Hagiography of Jumièges," 102. 
between 1024 and $1039,{ }^{22}$ whereupon no more copies were made of that text for at least thirty years. This marked falling off in production fits with Fulbert's claim that the Vita prima became obsolete. A handful of manuscripts containing Fulbert's Vita secunda survive from the 1070s onward, ${ }^{23}$ which indicates that he wrote his Vita secunda in the lull between ca. 1024 and the 1070s.

Fulbert the Author also rewrote a Life of Saint Romain (Vita tertia Romani) for the brothers of Rouen, beginning his work in a very similar way: "Dominis et confratribus suis sancte Rothomagensis ecclesie matris filiis, Fulbertus Peccator salutem." ${ }^{24}$ Again, Lifshitz places its moment of production fairly early, between 919 and 960, whereas Le Maho suspects that the text was produced after the translatio of Saint Romain in 1032. ${ }^{25}$ Nancy Gauthier thinks that the text was written around $1056^{26}$ and Constable places it in the late eleventh century. ${ }^{27}$ In any case, the oldest known manuscript (the so-called Livre d'ivoire) with this Life of

22. $B H L, 1061$, no. 7312 in Paris, Bibliothèque nationale de France, MS lat. 1805 (s.x); and $B H L, 30$, no. 181 in Avranches, Bibliothèque municipale, MS 99 (s.x-s.xi), in Arras, Bibliothèque municipale, MS 1029 (s.xil ${ }^{1 / 4}$ after 1006), in Boulogne-sur-mer, Bibliothèque municipale, MS 106 (probably copied from Arras 1029), and in Brussels, Koninklijke Bibliotheek, MS II 992 (ca. 1024/5-ca. 1035/9).

23. Rouen 1409 (Y.189) (ca. 1078-95); Bodley 852 (2611) (1070s); Cambrai 864 (1076-92); and Douai 867 (s.xi, prob. third quarter). The extensive dossier of Saint Romain has not yet been studied in enough detail to draw parallels.

24. BHL, 1061, no. 7313.

25. Jacques Le Maho, "La production éditoriale à Jumièges vers le milieu du Xe siècle," Tabularia: Sources écrites des mondes normands médiévaux 1 (2001): 11-32 at 31-32 and 32n78; Lifschitz, Norman Conquest, 178-79.

26. Nancy Gauthier, "Rouen pendant le Haut Moyen-Age (650-850)," in La Neustrie: Les pays au nord de la Loire de 650 à 850, ed. Hartmut Atsma, 2 vols. (Paris, 1989), 2:1-20 at 3n5.

27. Giles Constable, The Reformation of the Twelfth Century (Cambridge, 1996), 141. 


\section{Tjamke Snijders}

Saint Romain was produced around 1070. ${ }^{28}$ In short, the Vita tertia Romani must have been produced around 919 at the earliest, and around 1070 at the latest; but most likely between ca. 1032 and ca. 1070 .

Fulbert was a common name. ${ }^{29}$ Yet I am disinclined to assume the existence of two separate author-scribes who both called themselves "Fulbertus Peccator," had the unusual habit of signing their work, and flourished around the mid-eleventh century in northern France. ${ }^{30}$ There probably was but one Fulbertus Peccator, whose familiarity with Aichardus of Jumièges and Romanus of Rouen suggests that he was educated in Normandy-perhaps in the cathedral of Rouen, the monastery of Saint-Ouen, Jumièges, or Saint-Wandrille.

The people of Cambrai's traditional interest in Saint Aichardus strengthens the hypothesis that there was one Fulbert the Sinner who spent his youth in Normandy before

28. Rouen, Bibliothèque municipale, MS 1405 (Y.27), also known as the Livre d'ivoire of Rouen cathedral, was not bound together to its present form until the thirteenth century. The manuscript originally contained a list of bishops from Rouen that ends with Maurillius (1055-67) and the Acta archiepiscoporum Rotomagensium in this manuscript has been dated ca. 1070; see Richard Allen, "The Acta archiepiscoporum Rotomagensium: Study and Edition," Tabularia: Sources écrites des mondes normands médiévaux 9 (2009): 1-66 at 5. The Life and Office of Saint Romain appear as part of that same section.

29. Muzerelle, Manuscrits datés ... Cambrai, xxiii; David S. Spear, "Les doyens du chapitre cathédral de Rouen, durant la période ducale," Annales de Normandie 33 (1983): 91-120; Spear, "Les archidiacres de Rouen au cours de la période ducale," Annales de Normandie 34 (1984): 15-50.

30. The idea that Fulbert rewrote the miracles of Saint Audomarus (BHL, 122, no. 760) between 1036/7 and 1092 has recently been discredited (Allen, "Acta archiepiscoporum Rotomagensium," 12). Fulbertus Peccator has on occasion been identified with archdeacon Fulbert of Rouen (ca. 1047-ca. 1075), who may or may not have been the same person as Fulbert "the Sophist" who was in Saint-Évroult with Bishop Maurilius in 1056. One or other of these Fulberti may also have written the Acta archiepiscoporum Rotomagensium around 1070. 
moving to Saint-Sépulcre. This interest went back to the ninth century when the Normans had assaulted Jumièges. The monks of Jumièges had fled their abbey, taking the relics of Aichardus with them. ${ }^{31}$ They had taken refuge in the priory of Haspres, which was situated in the diocese of Cambrai only a few miles from the episcopal see. Even though Bishop Gerard I returned Aichardus's relics to Jumièges around 1038, the bishops of Cambrai continued to take an interest in Aichardus, Haspres, and Jumièges, and the Cambrai populace continued to venerate the saint. ${ }^{32}$ At Saint-Sépulcre's foundation in 1064, Bishop Lietbertus acquired a relic of "Sanctus Aicadrus abbas et confessor a cenobio Hasprehiensi" for his new community. ${ }^{33}$ Perhaps Fulbert was involved in this acquisition. We may suspect that he was a monk with an intimate knowledge of Saint Aichardus. Perhaps Bishop Lietbertus asked Fulbert to rewrite the old-fashioned Life of Aichardus when the relic

31. Jean Laporte, "La date de l'exode de Jumièges," in Jumièges: Congrès scientifique du XIIIe centenaire, Rouen, 10-12 juin 1954, 2 vols. (Rouen, 1955), 1:47-48 at 48.

32. Steven Vanderputten and Brigitte Meijns, "Realities of Reformist Leadership in Early Eleventh-Century Flanders: The Case of Leduin, Abbot of Saint-Vaast," Traditio 65 (2010): 47-74 at 57, 60-61. The name "Aichadre" figures in the 812 litany of Cambrai (Maurice Coens, "Anciennes litanies des saints," Analecta bollandiana 62 [1944]: 131-322 at 280) as well as in the litanies of several other monasteries in Cambrai, such as Marchiennes: "Aicadre" in Douai, Bibliothèque Marcelline Desbordes-Valmore, MS 68, fol. 8v, and "Aycadre" in Brussels, Koninklijke Bibliotheek, MS 14682 (see Coens, "Anciennes litanies," 278). Aichardus's life can be found in at least nine Cambrai manuscripts: Brussels II 992 from Saint-Ghislain; Douai, Bibliothèque Marcelline Desbordes-Valmore, MSS 151, 836, and 867 from Marchiennes; Cambrai, Bibliothèque municipale, MS 864 from Saint-Sépulcre; Arras, Bibliothèque municipale, MSS 14, 573, and 1029 from Saint-Vaast; and Valenciennes, Bibliothèque municipale, MS 514 from Saint-Amand). See also Charles Mériaux, Gallia irradiata: Saints et sanctuaires dans le nord de la Gaule du haut Moyen Âge (Stuttgart, 2006), 283-84.

33. Rodulf of Saint-Sépulcre, "Vita Lietberti," 868. 


\section{Tjamke Snijders}

was donated to Saint-Sépulcre, to re-ignite local interest for the saint. ${ }^{34}$ Unfortunately, I have no way to confirm or disprove such speculations. It is clear, however, that Fulbert the Sinner's expertise regarding the Vita Aichardi made him a person of some authority in Saint-Sépulcre.

\section{FULBERT AS "SCRIBE IN CHARGE"}

In Saint-Sépulcre Fulbert functioned as the "scribe in charge" of the scriptorium..$^{35}$ He single-handedly effected copies of Smaragdus's commentary on the Rule of Benedict, known as The Monk's Diadem, a very popular sermon on ascetic life by Ephraim the Syrian, ${ }^{36}$ Cassian's discussion of the rules and morality of monastic life and asceticism in the Institutions and Conferences, ${ }^{37}$ as well as a five-volume copy of Gregory the Great's Commentary in Job/Magna moralia, which he left unfinished..$^{38}$ As Denis Muzerelle puts it, "one is probably able to say at which leaf [Fulbert] died," as his hand begins to decline steadily from the fourth volume onwards, becomes almost unrecognizable in the fifth, and stops forever on fol. 89r. In total, Fulbert copied more than 1,100 folios of works that were essential for the monks in newly-founded Saint-Sépulcre. Through his copying activities, Fulbert taught the community members how to live their lives as monks.

Fulbert was not particularly concerned about the stylistic homogeneity of the manuscripts he produced. His hand

34. Cf. Howe, "Hagiography of Jumièges," 125.

35. For the term "scribe in charge," see Francis Newton, The Scriptorium and Library at Monte Cassino, 1058-1105, Cambridge Studies in Palaeography and Codicology 7 (Cambridge, 1999), 136n79.

36. Cambrai 819: Diadema monachorum and Liber de compunctione cordis (also known as Sermo asceticus).

37. Cambrai 247, 504.

38. Cambrai 215, 216, 217, 218, and 219; Muzerelle, Manuscrits datés ...

Cambrai, xxiii. 
varied quite significantly from manuscript to manuscript, which has led Muzerelle to remark that paleographers would probably not have tried to link all these manuscripts to the same person if Fulbert had not habitually left behind a colophon attesting to his work. ${ }^{39}$ But apart from the changes in hand-which may have been the simple result of getting older-he also varied the material characteristics of his manuscripts. The manuscripts he signed are all roughly equal in size, measuring between $230 \times 170 \mathrm{~mm}$. and $270 \times 180 \mathrm{~mm}$. (or $401-486 \mathrm{sq}$. cm.), and having 97 to 153 folios and 28 to 30 lines per page. The manuscripts that he co-wrote with other scribes in Saint-Sépulcre vary much more significantly, measuring between $190 \mathrm{x} 120 \mathrm{~mm}$. and $310 \times 220 \mathrm{~mm}$. (or 282-691 sq. cm.), and having 111 to 292 folios and 26 to 38 lines per page. The text block varies from $185 \times 125 \mathrm{~mm}$. (in Cambrai 215) to $250 \times 180 \mathrm{~mm}$. (Cambrai 807 ). In manuscripts that were written by multiple scribes, the text block is not even consistent within a manuscript: Cambrai 864, for example, has text blocks of 257 x $170 \mathrm{~mm}$., $256 \times 177 \mathrm{~mm}$., and $242 \times 181 \mathrm{~mm}$. While Fulbert punctuates Cambrai 215 with a media distinctio and punctus elevatus, most of the other Saint-Sépulcre scribes use the older system of subdistinctio, media distinctio, and distinctio. Fulbert's average initial is three lines high, while his colleagues usually left space for lager initials: 4.18 lines in Cambrai 864 or 4.69 lines in Cambrai 863. These numbers indicate that Fulbert may not have valued a strictly homogeneous and identifiable style for himself, and certainly did not impose it on his subordinates.

Fulbert cooperated with other monks in four manuscripts, all of which are hagiographical. ${ }^{40}$ Of the 820 folios containing saints' lives in these codices, he wrote one third ( 247 folios) by himself and left the rest to his monks. Ful-

39. Muzerelle, Manuscrits datés ... Cambrai, xxii.

40. Cambrai 807, 846, 863, and 864. 


\section{Tjamke Snijders}

bert started each codex with a praescriptio-he wrote the first couple of lines to set the size, spacing, and level of formality that was required in this manuscript and left his subordinates to finish the rest of the texts. ${ }^{41}$ The praescriptio indicates that Fulbert may have used the hagiographical codices as projects to train his scribes. Was that indeed his intention, and if so, what may his educational goals have been?

\section{CAMBRAI, BIBLIOTHÈQUE MUNICIPALE, MS 864}

Cambrai 864 throws some light on Fulbert's intentions. The manuscript contains the lives and passions of thirty-nine saints. Fulbert wrote the first five folios in this manuscript. ${ }^{42}$ The aspect of his script is small, regular, and rather square written at a very straight angle (see figs. 1-3). Among the most notable features of his hand is the morphology of $\mathbf{g}$, with a descender attached to the middle of the bowl and ending almost horizontally. He places $\mathbf{r}$ on the baseline, though long $s$ descends slightly below the line and consists of three strokes. He makes distinct wedges on his ascenders (which are not always placed at the top of the ascender), long descenders of $\mathbf{x}$, elongated caudatae consisting of two strokes in a $\mathbf{v}$-formation, and very broad, rounded ct-ligatures.

The other hands in the codex are of varying quality. Some of the most practiced hands are situated at the beginning. They try to imitate Fulbert's morphology, though they never quite manage to capture the square regularity

41. Sidney Tibbetts, "Praescriptiones, Student Scribes and the Carolingian Scriptorium," in La collaboration dans la production de lécrit médiéval: Actes du XIIIe colloque du Comité international de paléographie latine (Weingarten, 22-25 septembre 200o), ed. Herrad Spilling (Paris, 2003), $25-38$ at $26-32$.

42. For the identification of Fulbert's hand in this codex, see Muzerelle, Manuscrits datés ... Cambrai, 103. 


\section{Figure 1.}

Characteristic Letterforms the Hand of Fulbert the Sinner. Cambrai, Bibliothèque municipale, MS 864, fols. 23v, 24r, 125r (details).

g

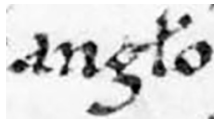

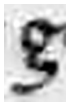

$\mathbf{r}$ and long $\mathbf{s}$

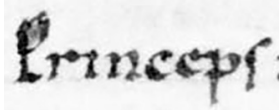

wedges on ascenders: $\mathbf{b}, \mathbf{d}$, and $\mathbf{l}$

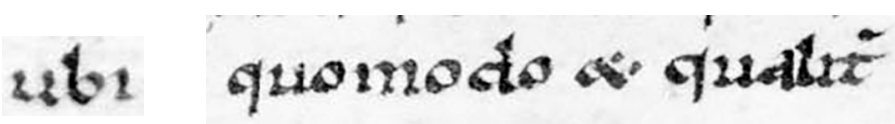

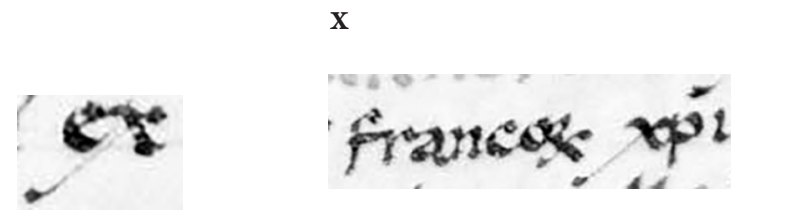

v-shaped caudata

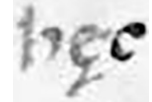

ct-ligature

cune he 


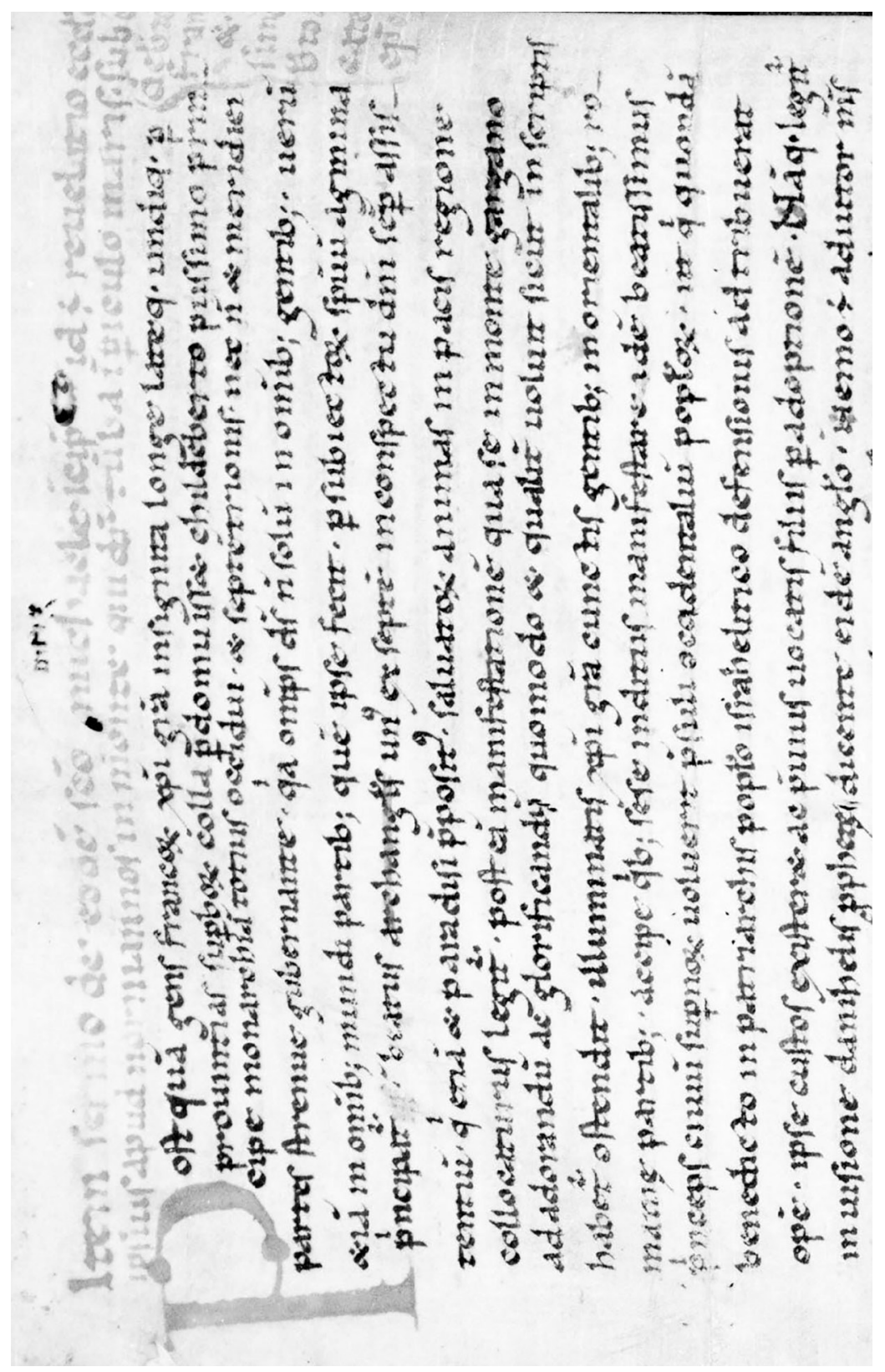

Figure 2.

Hand of Fulbert the Sinner.

Cambrai, Bibliothèque municipale, MS 864, fol. 23v.

(By permission of the Bibliothèque municipale, Cambrai) 


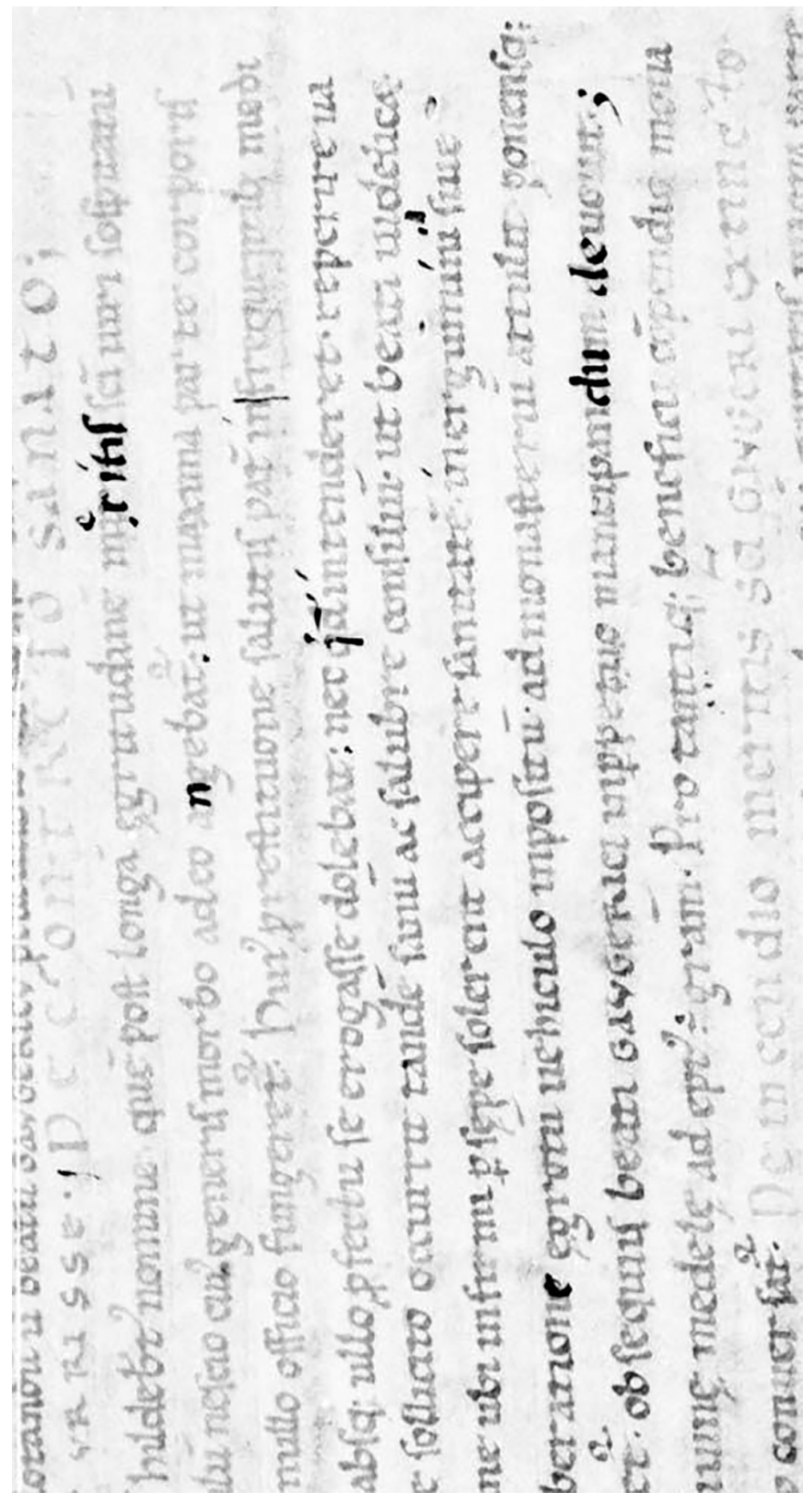

Figure 3.

Hand of Fulbert the Sinner.

Cambrai, Bibliothèque municipale, MS 864, fol. $125 \mathrm{r}$.

(By permission of the Bibliothèque municipale, Cambrai) 


\section{Tjamke Snijders}

of their master. The first scribe takes over from Fulbert at folio $5 r$, line 18 . He writes a very similar $\mathbf{g}$, places $\mathbf{r}$ on the baseline, and makes similar wedges on his ascenders. However, he also places long $s$ on the baseline, does not elongate $\mathbf{x}$, and makes curly caudatae and angular ct-ligatures. Even more importantly, his writing is not as square as Fulbert's (see fig. 4). This scribe wrote with a practiced hand that was struggling to imitate Fulbert's model. Other hands, however, are not as experienced and were struggling to get the words on the parchment, unable to emulate Fulbert's ductus and morphology.

Fulbert participated in all four codicological units that would eventually make up Cambrai 864 . The manner of his participation is a clear sign of his authority within the scriptorium, and it indicates that even though he let his subordinates write long stints on their own, he was there to supervise and finish their work for them.

A remarkably large number of hands are interspersed with Fulbert's writing (see table 1). ${ }^{43}$ The Saint-Sépulcre obituary lists three scribes for this period-Lanvinus, Rodulfus, and Erlebodus-but in Cambrai 864 it appears that more than ten scribes apparently cooperated, though it is difficult to distinguish between the various hands in this manuscript clearly. For a young monastery with a start-up scriptorium, this number is quite impressive. As a point of comparison: some fifteen scribes were active in the monastery of Michelsberg in Bamberg during the early twelfth century, out of the approximately seventy monks who inhabited that monastery. ${ }^{44}$ If this ratio of scribes to monks

43. For similar cases, see Léon Gilissen, L'expertise des écritures médiévales: Recherche d'une méthode avec application à un manuscrit du XIe siècle; Le lectionnaire de Lobbes, codex Bruxellensis 18018 (Ghent, 1973); and essays in La collaboration.

44. Karin Dengler-Schreiber, Scriptorium und Bibliothek des Klosters Michelsberg in Bamberg (Graz, 1979), 7-8, 75. The most prolific scribes here wrote about twenty books each, the "occasional" scribes about five; 


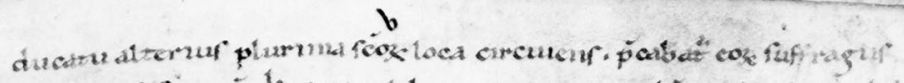

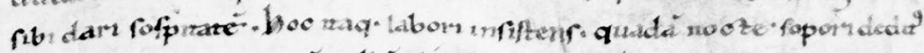

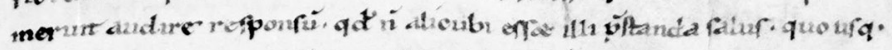

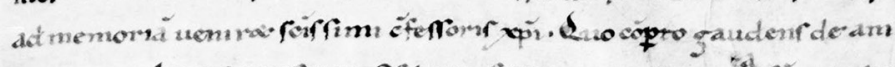

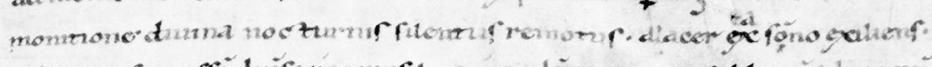

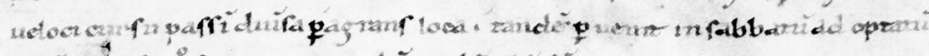

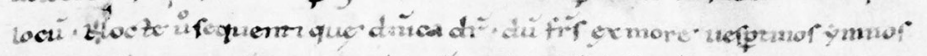

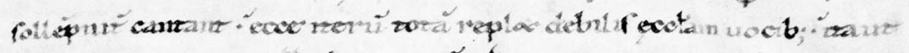
enźf

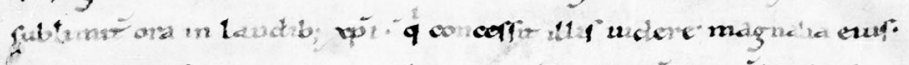

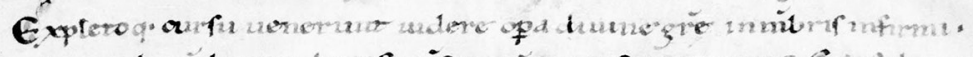

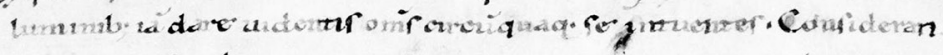

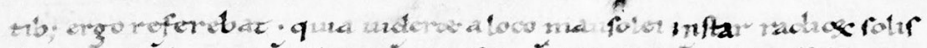

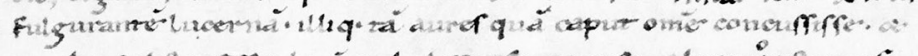

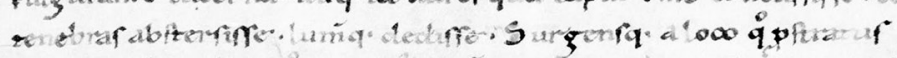

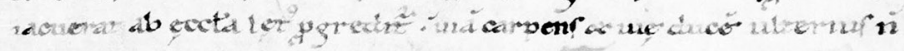

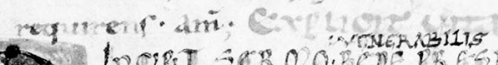
IRCRT ACR 0 OREDERESBRTRL IN DVODECID

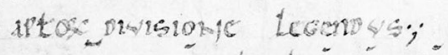

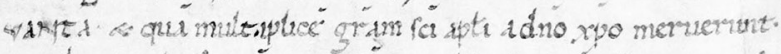

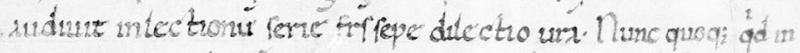

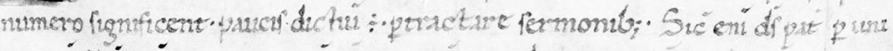

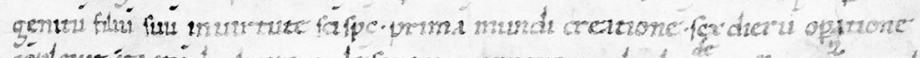

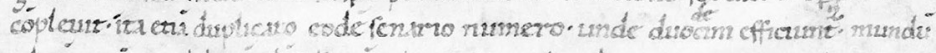

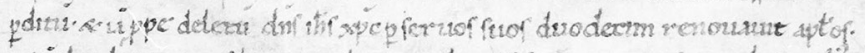

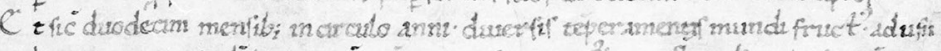

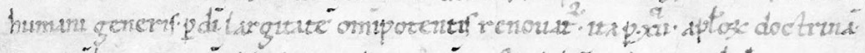

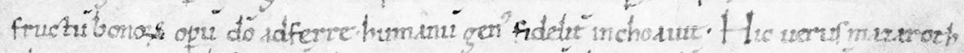

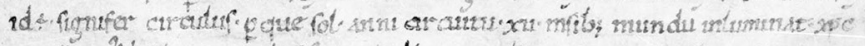

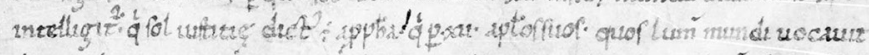

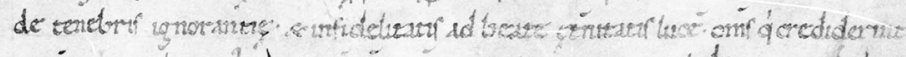

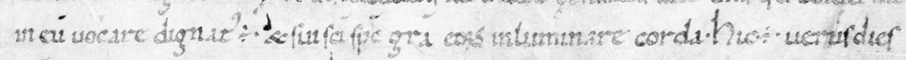

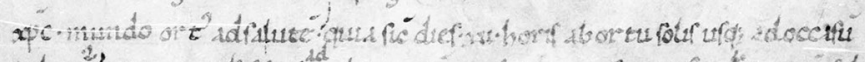

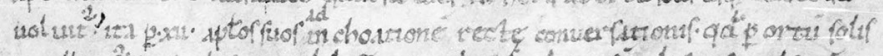

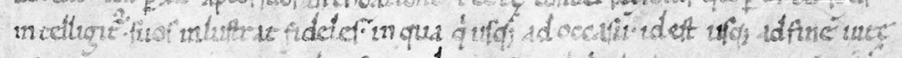

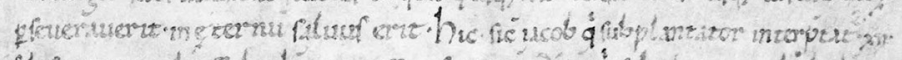

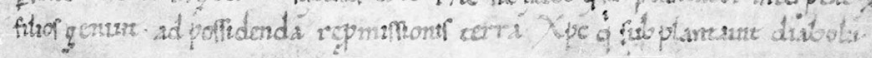

\section{Figure 4.}

Hand of Fulbert the Sinner (lns. 1-17) and another scribe (lns. 18-37). Cambrai, Bibliothèque municipale, MS 864, fol. $5 \mathrm{r}$.

(By permission of the Bibliothèque municipale, Cambrai) 
Table 1.

Codicological Units and Scribes in

Cambrai, Bibliothèque municipale, MS 864.

\section{Codicological Unit 1}

fols. $1 \mathrm{r}-5 \mathrm{r}$

Fulbert the Sinner

fols. $5 \mathrm{r}-23 \mathrm{r}$

multiple hands (about 3)

fols. $23 \mathrm{~V}-25 \mathrm{~V}$

Fulbert the Sinner

\section{Codicological Unit 2}

fols. $26 \mathrm{r}-124 \mathrm{r}$

multiple hands (about 11)

fols. $124 \mathrm{~V}-125 \mathrm{~V}$

Fulbert the Sinner

\section{Codicological Unit 3}

fols. $126 \mathrm{r}-149 \mathrm{r}$

multiple hands (about 2)

fols. 149r-149bisr

Fulbert the Sinner

\section{Codicological Unit 4}

fols. $150 \mathrm{r}-176 \mathrm{r}$

fols. $176 \mathrm{v}-208 \mathrm{r}$

fols. $208 \mathrm{~V}-214 \mathrm{~V}$

fols. $215 \mathrm{r}-241 \mathrm{r}$

fols. $241 \mathrm{r}-273 \mathrm{~V}$ multiple hands (about 2)

Fulbert the Sinner

another hand (1 or more)

Fulbert the Sinner

multiple hands (about 5) 
is at all representative, more than ten professional scribes in Saint-Sépulcre would indicate a monastery of more than fifty monks. As many of the region's monasteries only housed between eight and eighteen monks in the late eleventh century, a complement of more than fifty monks would have turned Saint-Sépulcre into one of the most important and most commented-upon monasteries in the region. ${ }^{45}$ This was clearly not the case. As we have seen, only "Abbot Walter and ten poor monks" inhabited the monastery in 1079, and nothing suggests that the monastery experienced sudden growth between 1080 and 1092. It is, therefore, unlikely that the hands in these codices all belonged to "professional," "full-time" scribes in the employ of Abbot Walter.

Two explanations for the abundance of hands in Cambrai 864 present themselves. The first is that scribes from Saint-Sépulcre only wrote a small part of the manuscript and that Fulbert used the services of several external scribes. He may have toured neighboring religious houses with the unfinished Cambrai 864, or he may have asked scribes from other monasteries or institutions to spend some time in Saint-Sépulcre to assist with manuscript production. However, the inexperience of many of the scribal hands argues against this hypothesis. From a "professional" scribe from

see Michael Gullick, "How Fast Did Scribes Write? Evidence from Romanesque Manuscripts," in Making the Medieval Book: Techniques of Production. Proceedings of the Fourth Conference of the Seminar in the History of the Book to 150o, Oxford, July 1992, ed. Linda L. Brownrigg (Los Altos, CA, 1995), 39-58 at 44.

45. An ideal number of monks was often thought to be around fifty, but numbers in this region were often down as low as twelve (Saint-Bertin in 1095-1123), eight to ten (Saint-Trond in the early twelfth century), and eighteen (Saint-Martin in Tournai in 1093). See Steven Vanderputten, "Monastic Recruitment in an Age of Reform (1oth-12th Centuries): New Evidence for the Benedictine Abbey of Saint-Bertin," Revue benedictine 122 (2012): 232-51 at 244, 246. 


\section{Tjamke Snijders}

the cathedral of Cambrai or one of Saint-Sépulcre's nearby abbeys such as Saint-Vaast or Saint-Amand, one expects 22 reasonably regular and legible hands that are free from the typical errors made by scribes in training. However, Cambrai 864 is filled with irregularities, awkward decisions, and other evidence of general inexperience.

One of the most apparent signs of greenness in the manuscript is the irregularity of the ruling; the monks usually ruled manuscripts themselves and it did not require any particular talent to do so, just a bit of experience. ${ }^{46}$ Armed with a dry point and a ruler, the individual who prepared the parchment had to exert light pressure on his pen to press about thirty parallel lines into a piece of parchment, which could then be used to write upon. The evenness of the distance between the lines was key. However, in Cambrai 864 the lines are sometimes crooked, and the distance between them is far from even (see fig. 5). On folios $23 \mathrm{r}$ and $258 \mathrm{r}$, for example, the smallest distance between two ruling lines measures $5.6 \mathrm{~mm}$. and the largest $9.8 \mathrm{~mm}$., which is a $77 \%$ difference. Around folio 100, the person who was ruling the parchment exercised so much force on his dry point that he repeatedly cut right through the parchment.

The second sign of general inexperience is the tendency to misjudge the amount of space that would be required to transcribe a text, even though (as we shall see) the scribes worked from excellent exemplars. Many scribes either left

46. Monasteries regularly started to buy fully prepared quires from commercial merchants only in the twelfth century (Gullick, "How Fast did Scribes Write?," 40). Thus, the Saint-Sépulcre scribes would likely have ruled their own manuscripts; compare Gullick, "How Fast did Scribes Write?" 54n12, and Richard Gameson, "A Scribe's Confession and the Making of the Anchin Hrabanus (Douai, Bibliothèque Municipale, Ms. 340)," in Manuscripts in Transition: Recycling Manuscripts, Text and Images; Proceedings of the International Congress Held in Brussels (5-9 November 2002), ed. Brigitte Dekeyzer and Jan Van der Stock (Paris, 2005), 65-79. 


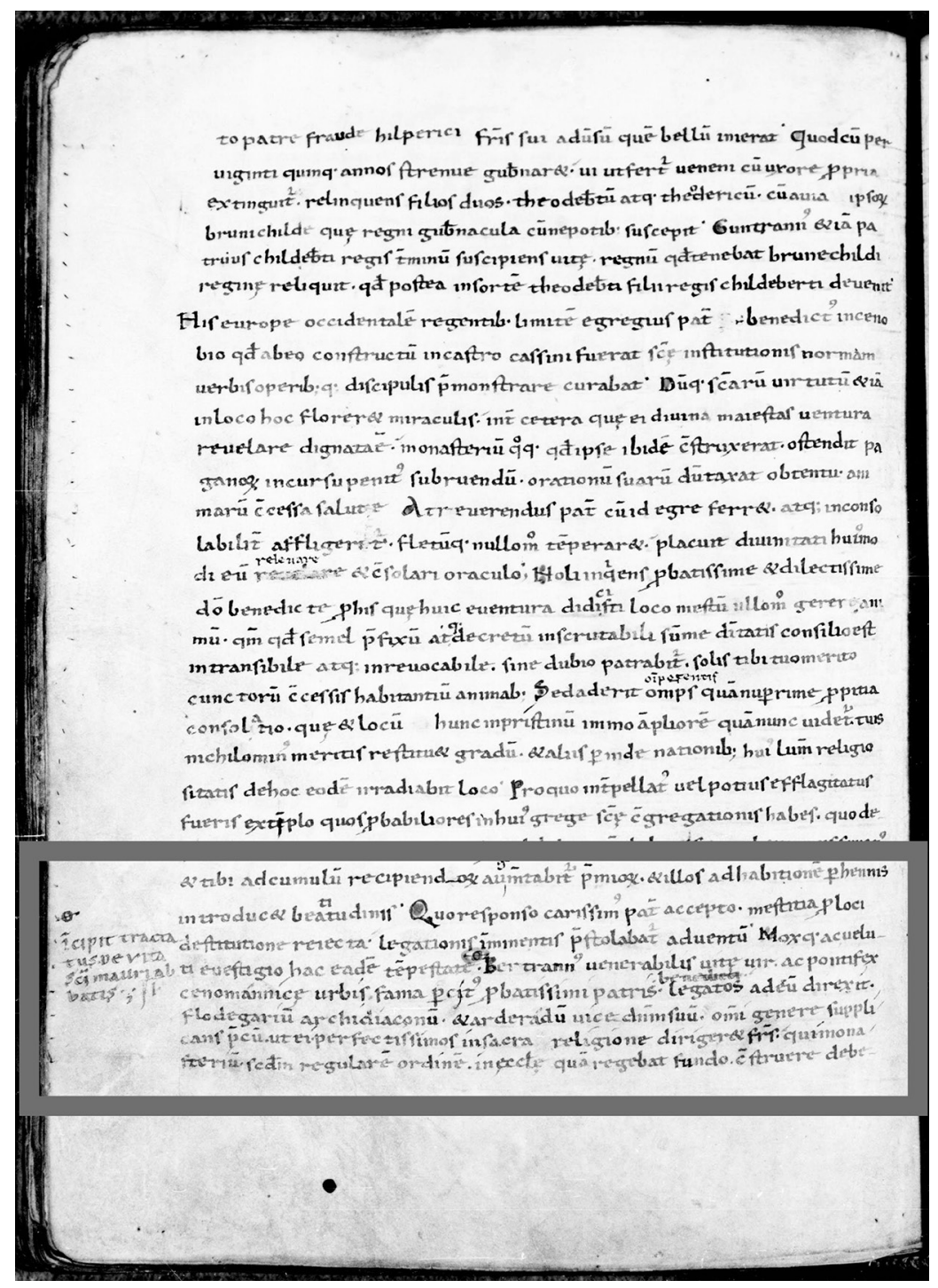

Figure 5.

Example of inexpert ruling and writing.

Cambrai, Bibliothèque municipale, 864, fol. $257 \mathrm{v}$.

(By permission of the Bibliothèque municipale, Cambrai) 


\section{Tjamke Snijders}

insufficient space at the start of a text for the rubricator to insert the title or else greatly overestimated the amount

24 of space that would be needed (e.g., fols. 6r, 23v, 25r, 92r, $100 \mathrm{v}, 11 \mathrm{or}, 123 \mathrm{~V}, 126 \mathrm{r}, 188 \mathrm{r}, 198 \mathrm{v}$, and $272 \mathrm{r}$ ). On five occasions, there was not enough room for a text to fit allotted, so the scribes had to reduce the size of the script and squeeze the last lines onto the margins (e.g., fols. $5 \mathrm{~V}, 49 \mathrm{~V}, 124 \mathrm{~V}-125 \mathrm{~V}$, $202 \mathrm{~V}-2 \mathrm{O} 4 \mathrm{r}$, and 241v-242r).

The third indication of lack of experience is manifest in the failure to coordinate a consistent layout. The fourth codicological unit of Cambria 864 starts with twenty-one folios laid out in two columns, whereas the preceding three units were written in long lines. When the scribe realized his mistake, he switched to long lines right in the middle of the text (fols. 171v-172r). Two folios later, Fulbert himself took over and wrote a lengthy stint of thirty-two folios himself-perhaps in sheer exasperation with the performance of his charges.

The other three hagiographical manuscripts in which Fulbert the Sinner participated evince the same general pattern. In Cambrai 807 Fulbert shows his leadership by writing the opening and closing pages of the codex (fols. 1r-17v and 109r-111v), but in between is a multitude of anonymous and often irregular hands. Cambrai 846 is mainly written by Fulbert (fols. 51v-144v), with the first fifty-one folios written only by two other scribes. In Cambrai 863 , which is the sister volume to Cambrai 864 , Fulbert wrote fols. $2 \mathrm{~V}-7 \mathrm{v}, 41 \mathrm{v}$, 200 rb-254r, and possibly 61r, 142r, and 173r. Irregular hands that were prone to mistakes wrote the other folios. Though the codicological structure of this manuscript makes it harder to determine exactly which corrections were added at what time, it is clear the scribes repeatedly forgot to copy paragraphs and squeezed them into the margins (e.g., fol. 219r) or added them on scrap fragments of parchment (e.g., fols. $27 \mathrm{r}, 91 \mathrm{r}, 168 \mathrm{r}, 173 \mathrm{r}$ ). They forgot to copy the explicit or the incipit of a text on two occasions (fols. 109r, 113r), and generally failed to agree on a common layout. 
From this combination of elements, it seems impossible that a group of highly experienced scribes from other institutions was asked to collaborate on these manuscripts. A second explanation for the number of hands that can be discerned in Cambrai 864 presents itself, namely, that virtually all Saint-Sépulcre's monks who knew how to write (in the technical sense of the word) were asked to participate in the production of this manuscript.

\section{TEACHING THE SCRIBES}

Were all these people learning how to write in a "house style" under the guidance of Fulbert the Sinner? All the hands show a basic similarity, influenced at least by the fact that the scribes were all writing in the same environment, at the same time, and using the same exemplars, but they do not appear consciously to imitate Fulbert's hand. As can be seen in a comparison of Fulbert's formation of the letter $\mathrm{g}$ and ex-ligatures with those of other scribes (see fig. 6 and compare to fig. 1), it is clear these scribes did not attempt to imitate the morphology or ductus of Fulbert's writing. ${ }^{47}$ The descender of $\mathbf{g}$, for example, is sometimes open and sometimes closed, and is usually attached to the right of the upper bowl and sometimes to the left, but never in the middle as was Fulbert's habit. Similar observations can be made for other letters and ligatures. Fulbert apparently placed no high value on stylistic homogeneity within the manuscripts produced under his guidance.

This lack of stylistic homogeneity also applies to the illumination and layout of these codices. The texts in Cambrai 846 were written in two columns of twenty-six lines, while the texts in other manuscripts were written in long lines from thirty-two (Cambrai 807) up to thirty-eight (Cambrai 863 ). The titles of saints' lives are sometimes executed as 
Figure 6.

Hands of Various Scribes in

Cambrai, Bibliothèque municipale, MS 864

Showing Formation of "g" and "ex".

fol. $27 \mathrm{r}$
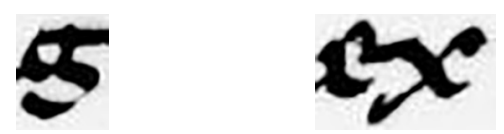

fol. $83 \mathrm{r}$
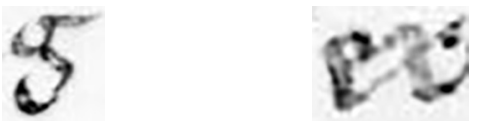

fol. $97 \mathrm{r}$
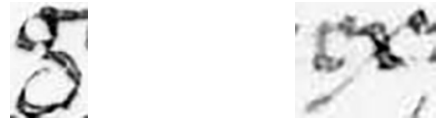

fol. $143 \mathrm{r}$
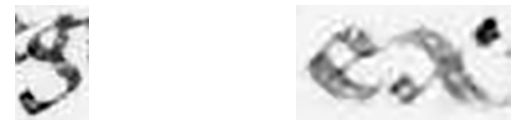

fol. $210 \mathrm{r}$
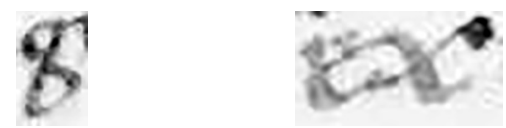

fol. $242 \mathrm{r}$
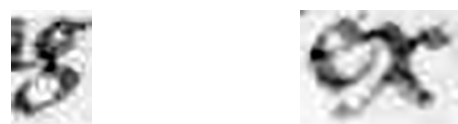
rubrics, in red undercast letters, and sometimes written in capitals in-filled with red, green, or yellow pigment. These variations in layout have no specific significance. They do not change the meaning of the texts. They only indicate the lack of coordination between scribes. What these manuscripts do have in common, however, is that they were all executed in a simple layout that did not require the intervention of a trained illuminator. The initials are small and plain, colored in red with sometimes a dot of green or yellow, but with no decoration to speak of-the scribes themselves evidently did them. A small number of initials were illuminated more elaborately, though in a rather crude style. They may be later additions, or perhaps practice runs of an aspiring illuminator among the Saint-Sépulcre scribes.

Were the scribes forgoing to coordinate the style of their codices because they were in too much of a hurry? Probably not. They wrote their texts using the relay method, in which one scribe writes some lines, then stops (often at a seemingly random point), at which point another scribe takes over. ${ }^{48}$ The scribes alternated frequently and often wrote but very short fragments of text. The following example from Cambrai 864 (see figs. 7-8) demonstrates the frequency of these changes: two hands wrote folio $81 \mathrm{v}$ (A, lns. 1-9; and B, lns. 10-36); at the top of folio 82r hand A began again (lns. 1-18), was interrupted by B (lns. 19-24), who was corrected by a later hand $\mathrm{X}$; and hand $\mathrm{A}$ took over again and finished the folio (lns. 25-36).

This writing method did not facilitate or expedite the production process, because the scribes had to wait for one another to finish before they could start writing their lines, instead of being able to work simultaneously. The hands keep alternating throughout the codex-sometimes writing thirty folios, sometimes just a couple of lines. The most reg-

48. Benjamin Victor, "Simultaneous Copying of Classical Texts 8oo1100: Techniques and Their Consequences," in La collaboration, 325-45. 


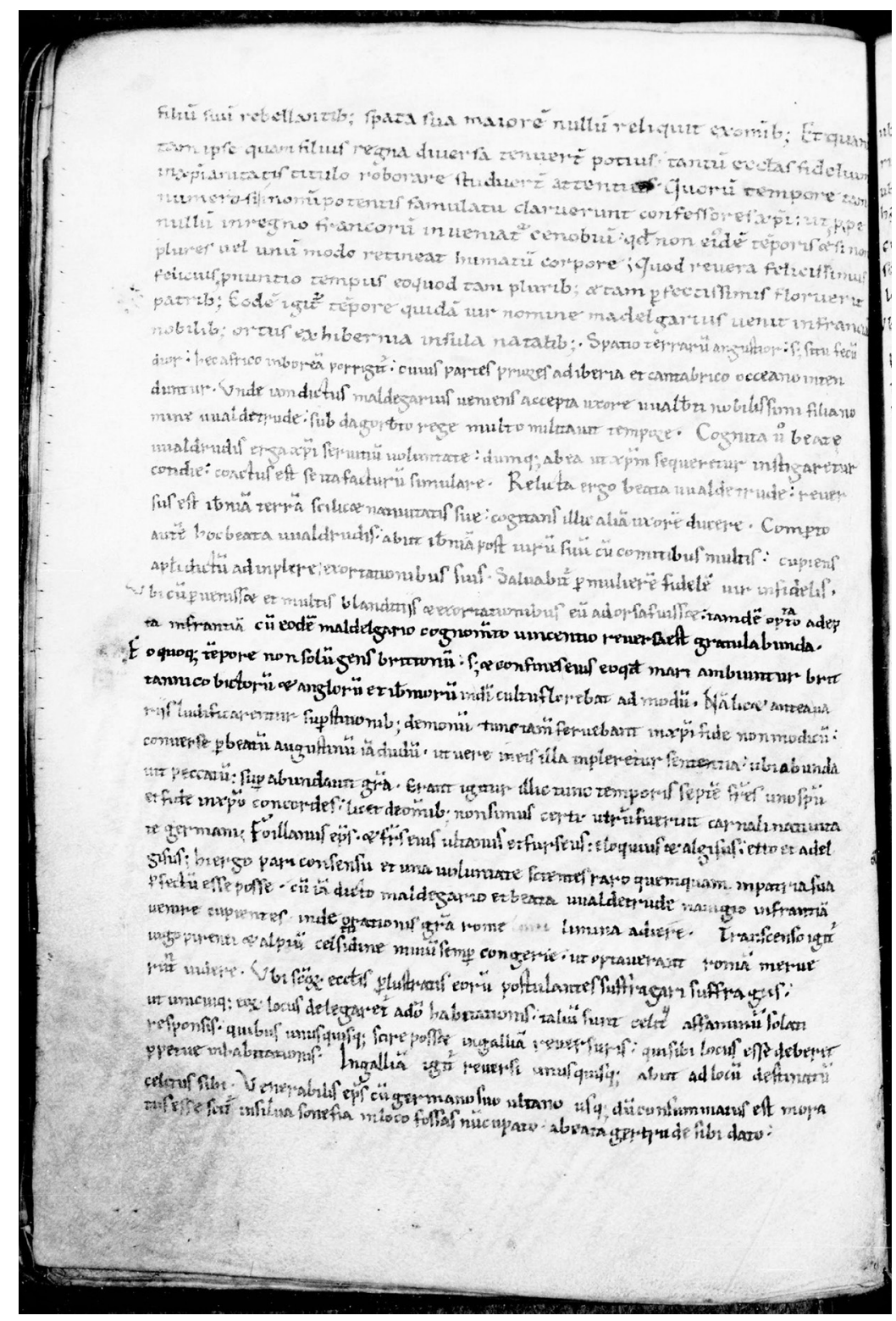

Figure 7 .

Hands A (lns. 1-9) and B (lns. 10-36).

Cambrai, Bibliothèque municipale, 864, fol. 81v.

(By permission of the Bibliothèque municipale, Cambrai) 


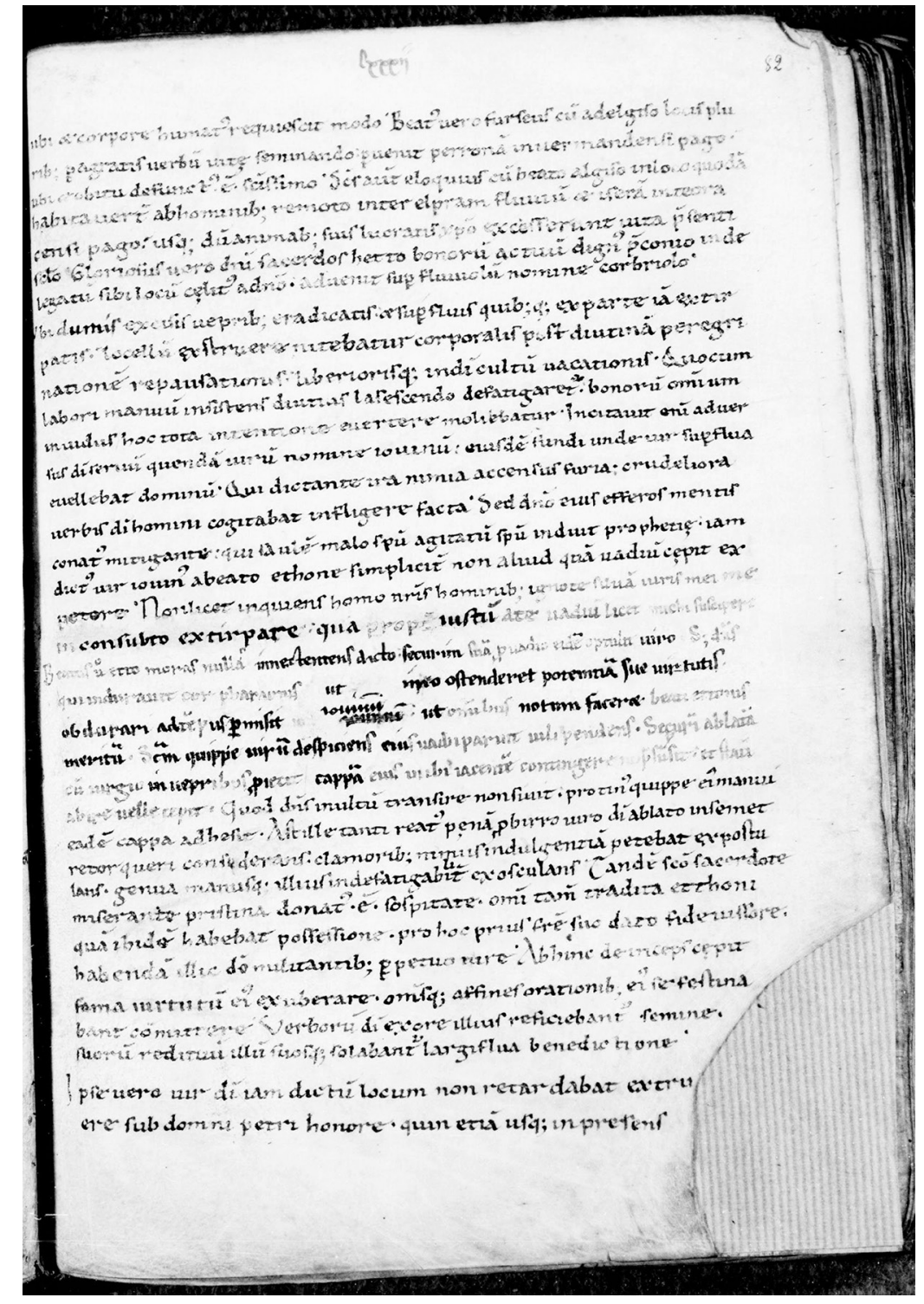

Figure 8.

Hands A (lns. 1-18 and 25-36) and B (lns. 19-24).

Cambrai, Bibliothèque municipale, 864 , fol. 82r.

(By permission of the Bibliothèque municipale, Cambrai) 


\section{Tjamke Snijders}

ular hands tend to write longer fragments of texts, whereas the untrained hands only write a few lines. The fairly irregular hand B, for example, contributed only four short pieces and wrote no more than one folio in total-as if his participation in the codex were tolerated rather than encouraged.

While Fulbert the Sinner single-handedly copied hundreds of folios with important spiritual texts, he could not fill Saint-Sépulcre's entire library by himself. He conceivably requested the participation of his colleagues, even if they were unqualified, for the less critical manuscripts. Those who were able to hold a pen may have dashed off to the scriptorium in between the liturgical hours to do their bit. This working method would explain the inexperienced hands, the short writing stints, and the frequent changes of ink in the midst of a folio.

The most inexperienced hands are concentrated in the second codicological unit of Cambrai 864 (fols. 26r-125V). Fulbert had acquired an excellent exemplar for these folios, one that was fit to be copied with only minimal changes, so that the copying process of fols. 26-125 should have been straightforward enough for beginners. This exemplar (Cambrai, Bibliothèque municipale, MS 865) was produced shortly after 1051 in the Cathedral of Cambrai. ${ }^{49}$ The Cathedral and Saint-Sépulcre were situated at walking distance from one another in the city of Cambrai and both owed loyalty to the bishop. As a result, the two institutions maintained very close contact during the last quarter of the eleventh century, and the canons apparently lent Cambrai 865 to their neighbors..$^{50}$ This manuscript consisted of three codicological units. The first (fols. 1r-71r), which was produced in the first half of the eleventh century and was probably not, in fact, produced in the Cathedral of Cambrai, concentrated fully on Saint Rémi, the archbishop of Reims, and

49. See Muzerelle, Manuscrits datés ... Cambrai, 103.

50. Ibid., xxiii. 
was copied integrally into Cambrai 864 . The second unit (fols. 72r-75r) is a later addition of two bifolia with the life of Giles of Athens. ${ }^{51}$ And the third unit (fols. 76r-171r) contains a Life of Saint Géry, dedicated to Bishop Gerard I of Cambrai (1012-51), as well as a selection of fourteen saints' lives, seven of which were copied into the manuscript from Saint-Sépulcre.

The scribes of Saint-Sépulcre copied most of the saints from the exemplar in their original sequence, as can be seen in table 2. Around the end of the eleventh century, it was still somewhat unusual to copy a hagiographical exemplar so fully. Scribes in this area would typically compile hagiographical manuscripts from a large number of exemplars, copying only those texts that held a particular interest for their specific community.5. The idea of a fixed list of saints (other than the apostles) who were important to all communities only started to gain ground in the second half of the twelfth century, and would become truly popular with Jacob de Voragine's Golden Legend (ca. 1265). Around the end of the eleventh century, the relatively slavish copying of a collection of saints' lives was a sign of extreme reverence for the exemplar, or similarly special circumstances.

The Saint-Sépulcre scribes copied each text in their exemplar as faithfully as possible. A critical edition of the

51. BHL, 107, nos. 93-94.

52. Diane J. Reilly, "The Cluniac Giant Bible and the Ordo librorum ad legendum: A Reassessment of Monastic Bible Reading and Cluniac Customary Instructions," in From Dead of Night to End of Day: The Medieval Customs of Cluny, ed. Susan Boynton and Isabelle Cochelin (Turnhout, 2005), 177-78, 182-83; Tjamke Snijders, Manuscript Communications: Visual and Textual Mechanics of Communication in Hagiographic Manuscripts from the Southern Low Countries (Turnhout, 2015), 148-75, 323-31. In 1131 Saint-Sépulcre possessed twenty-eight relics from the Cambrai area, including those of "Sanctus Gaugericus episcopus et confessor ab urbe Cameracensi," "Sanctus Etto confessor a [villa Dompierre]," and "Sanctus Vincentius confessor a vico Sonegias"; see Rodulf of Saint-Sépulcre, "Vita Lietberti," 868. 


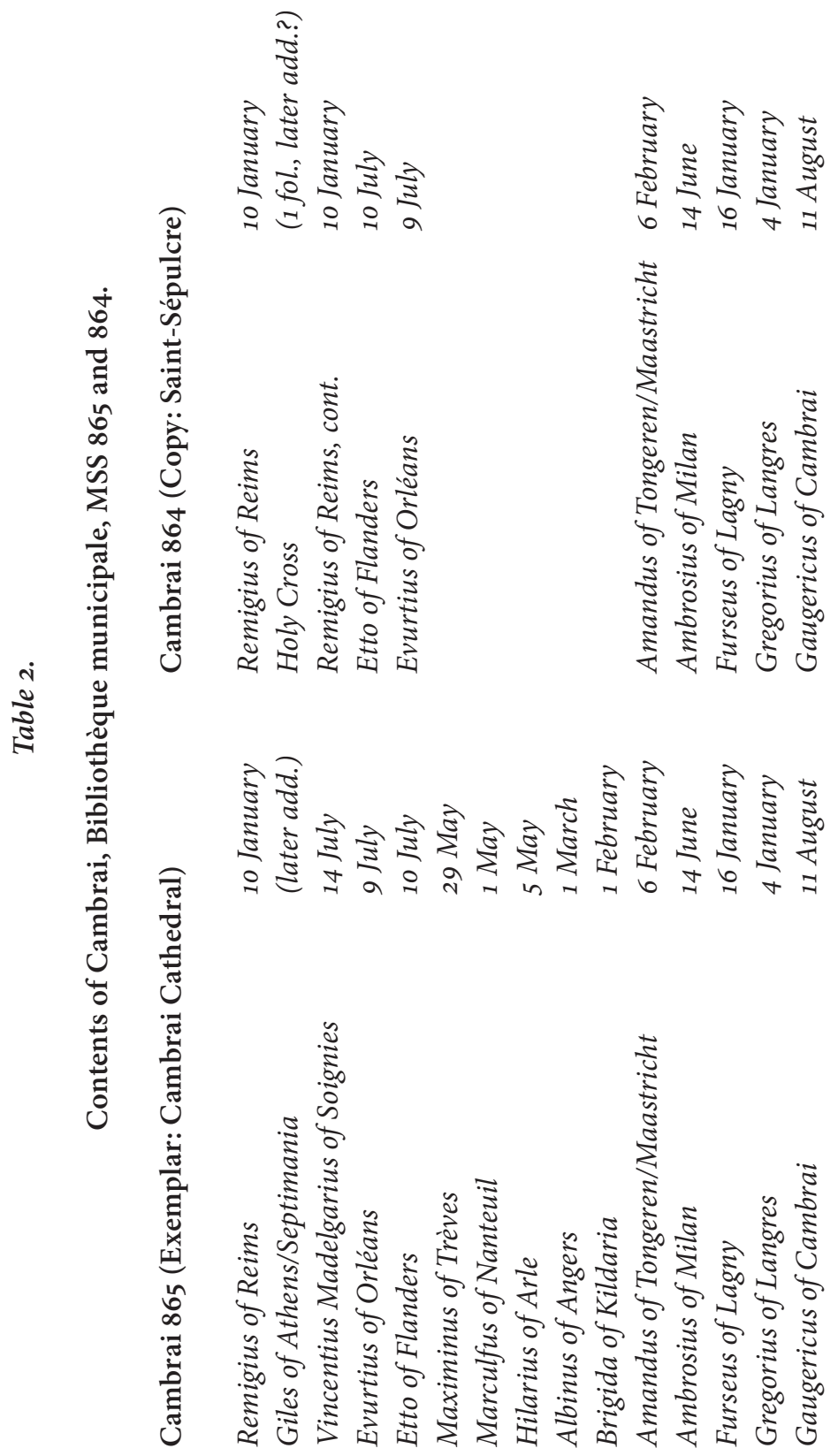


Vita tertia Gaugerici in Cambrai 865 and Cambrai 864 by Steven Vanderputten and Diane Reilly shows a negligible amount of textual variants between the two manuscripts. ${ }^{53}$ While the Saint-Sépulcre scribes did not copy the lives of seven saints in Cambrai 865 that apparently did not interest them-some because they may have been too foreign, others because they already possessed a copy of their life-they did not consciously try to rewrite the texts or otherwise improve on their exemplar. ${ }^{54}$ The only scribe in Saint-Sépulcre who played with the text in Cambrai 865 and strove to improve it was Fulbert the Sinner. When his fellow monks had faithfully copied the Vita tertia Gaugerici with one folio to spare, he used that folio to squeeze in four new miracles of Gaugericus, which he probably authored himself.55

Cambrai 865 was an easy exemplar to work with because it was neatly written and its layout was clear and not unlike that of Cambrai 864. In other words, it must have been relatively easy to copy this manuscript, even for an inexperienced scribe. The monks from Saint-Sépulcre who worked on the second codicological unit thus did not need to be creative or to make hard decisions, but only had to reproduce the text and layout of the exemplar before them.

The Life of Saint Humbertus, elsewhere in the manuscript, shows the risk of giving these inexperienced scribes less-than-perfect exemplars. Humbertus was the founder of the Abbey of Maroilles at some twenty-five miles from the

53. Gerard of Cambrai, Acta Synodi Atrebatensis, Vita Autberti, Vita tertia Gaugerici, Varia scripta ex officina Gerardi exstantia, ed. Steven Vanderputten and Diane Reilly, Corpus Christianorum, Continuatio medievalis 270 (Turnhout, 2014), 141.

54. When Bishop Lietbertus founded Saint-Sépulcre in 1064, he donated a relic of Vincentius Madelgarius of Soignies. This saint's Life was not copied into Cambrai 864, but that can hardly be because the monks were not interested in him. In all probability, they already possessed a Life of this saint. See Rodulf of Saint-Sépulcre, "Vita Lietberti," 868.

55. Acta Synodi Atrebatensis, 141-42. 


\section{Tjamke Snijders}

city of Cambrai. ${ }^{56}$ His Vita was an important text for the community of Saint-Sépulcre because Bishop Lietbertus had donated one of Humbertus's relics to them. ${ }^{57}$ One of the Saint-Sépulcre scribes began to copy Humbertus's Vita pri$m a,{ }^{58}$ but neglected to read through the entire text of his exemplar before he started his copying work. He copied down how Humbertus was born in the time of Childeric II and lived an exemplary life in the Church. ${ }^{59}$ One day, Humbertus decided to visit his parents' possessions in Rome, traveling with Saints Amandus and Nicasius. When a bear killed one of the saints' packhorses, Humbertus made the beast carry their luggage. After his sojourn in Rome, Humbertus returned home, but he pined for the papal city and made another pilgrimage. The pope then ordered him to go back and construct a church.

At this moment in the story, the scribe's working method caused a severe difficulty. When he was about to start copying folio 141r, he learned that Humbertus indeed returned home and received permission from the bishop of Cambrai to found a monastery on his land of Maricolas (Maroilles), whereupon twelve monks came to live there. However, Humbertus soon realized that his monks would not prevail on the path of the Rule of Benedict ("Videns autem postea quia monachorum congregatio ibidem juxta tramitem regulae sancti Benedicti non valeret esse"). He, therefore, decided to abandon his monastery and instead construct a far

56. Anne-Marie Helvétius, "Réécriture hagiographique et réforme monastique: Les premières Vitae de Saint Humbert de Maroilles (Xe-XIe siècles), avec lédition de la Vita Humberti Prima," in La réécriture hagiographique dans l'Occident médiéval: Transformations formelles et idéologiques, ed. Monique Goullet and Martin Heinzelmann (Ostfildern, 2003), 195-230.

57. Rodulf of Saint-Sépulcre, "Vita Lietberti," 868.

58. BHL, 601, nos. 4037-38.

59. Cambrai 864, fol. 139v. The scribe copied chapters 2-7; see Helvétius,

"Réécriture hagiographique," 221-24. 
more popular house for canons in the vicinity. The rest of the Vita prima deals with Humbertus's life as the head of this chapter.

Imagine our scribe's surprise. This Vita prima was not a story that celebrated the life of Humbertus as the abbot of Maroilles, and would not exactly inspire the monks of newly-founded Saint-Sépulcre. He immediately stopped his copying work, and presumably did some further research (or asked Fulbert the Sinner for help). He soon discovered that between 1030 and 1035 a Vita secunda Humberti had been composed in which Humbertus did found the monastery of Maroilles, embrace the Rule of Benedict, and remain Maroilles's abbot until his death around 680 .

An experienced scribe could have solved this problem without too much difficulty, combining the beginning of the Vita prima with the ending of the Vita secunda-a challenging task, but not an insurmountable one. Alternatively, he could have cut folio 140r-v from the codex, scraped the text on folio 139v, and created a palimpsest, thus replacing the Vita prima with the Vita secunda. However, being inexperienced, this scribe simply crossed out the part of the Vita prima he already wrote, tried to scrape the text from the first folio but failed to do so in a way that would permit him to create a palimpsest, and quickly abandoned his attempts (see fig. 9). He just continued on folio 141v with the Vita secunda as if nothing had happened, using a different pen and ink (see fig. 10).

The scribes of Cambrai 864 were clearly given a measure of individual responsibility to pick and choose their texts. If an experienced scribe such as Fulbert had been intimately involved in matters of text choice, obvious mistakes as with the Vita prima Humberti would either not have been made at all, or would have been solved more professionally. Fulbert was either too busy to supervise these monks as closely as he should have, or he consciously let his subordinates make their own mistakes, perhaps judging that in this particular case, their participation in the process of 


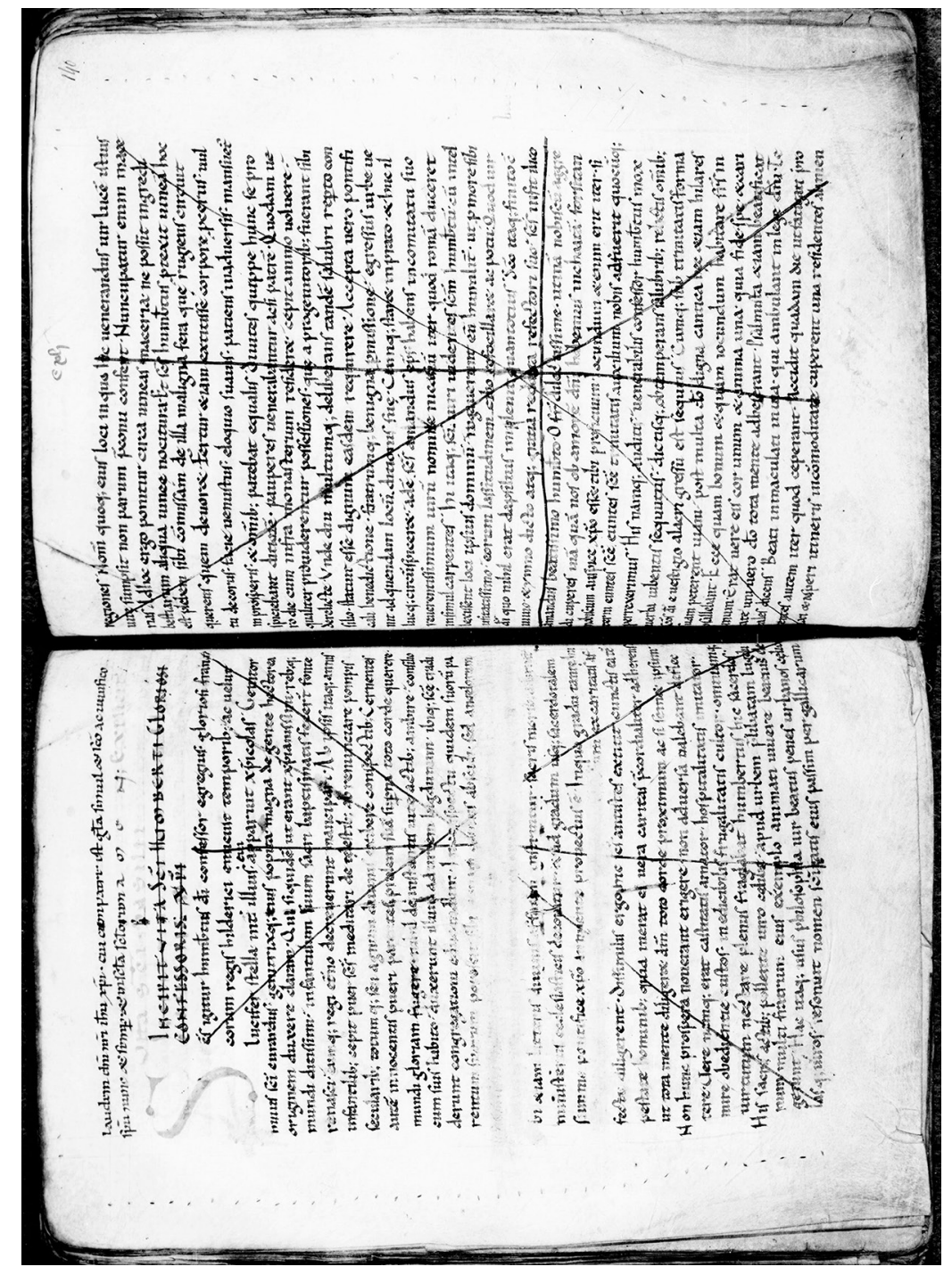

Figure 9.

Opening of the Vita prima Humberti.

Cambrai, Bibliothèque municipale, 864 , fols. $139 \mathrm{v}-14$ or.

(By permission of the Bibliothèque municipale, Cambrai) 


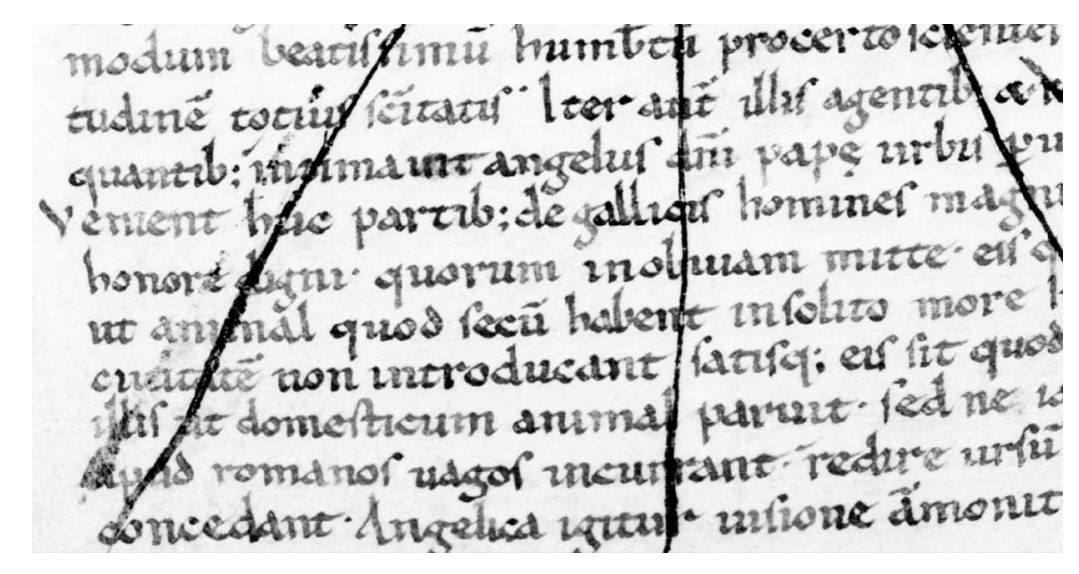

Figure 1oa.

Hand of the Vita prima Humberti.

Cambrai, Bibliothèque municipale, 864, fol. 141v.

(By permission of the Bibliothèque municipale, Cambrai)

Dxrn-

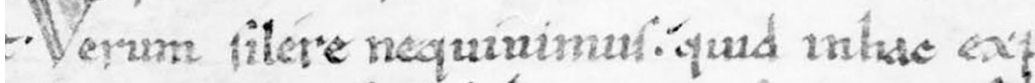

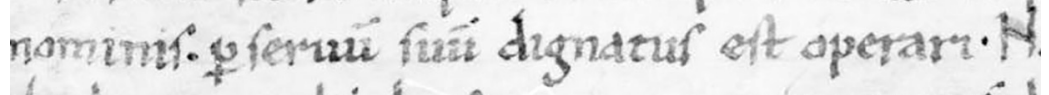

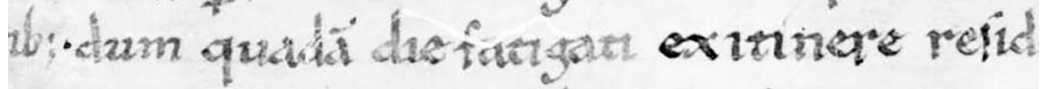
an vecredrent esce fubto exfilus ofus for

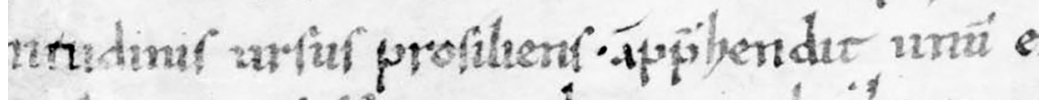
pof

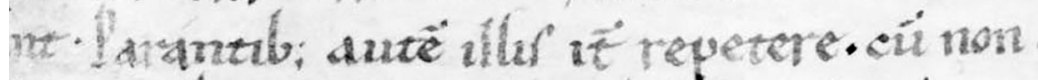

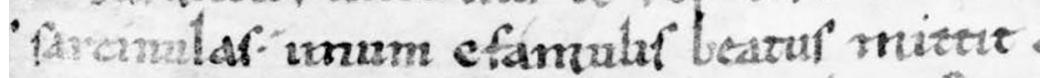

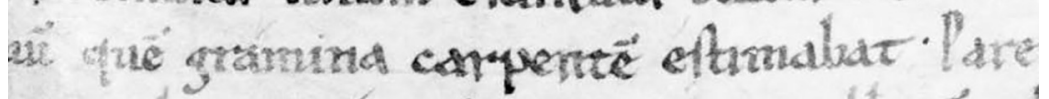

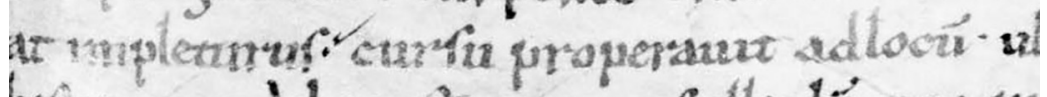

Figure 10 .

Hand of the Vita secunda Humberti.

Cambrai, Bibliothèque municipale, 864, fol. 143r.

(By permission of the Bibliothèque municipale, Cambrai) 


\section{Tjamke Snijders}

creation was more important than the aesthetics of the end result. This last point deserves some further investigation.

38 Was there some sort of spiritual value to writing Cambrai 864 as a team effort? On the surface, the situation is reminiscent of Richard Gameson's study of a manuscript with canon law from the nearby monastery of Saint-Vaast that was produced by nine scribes in twelve stints. These scribes all signed their work and asked for the monastery's patron saint to accept their work and look after them. ${ }^{60}$ Gameson classified this manuscript as "an exercise in recording and apotheosing the scriptorium itself." However, in the case of Saint-Sépulcre, it was not a small team of welltrained scribes but a less experienced group of monks who produced the codex - and instead of writing a high-status, luxury manuscript with canon law that was meant for an expert audience, they worked on a middle range hagiographical codex.

The choice of genre is meaningful, as hagiography was among the few genres in an eleventh-century monastery that did not need to be copied perfectly and flawlessly. In copying the Bible, the sacred nature of the text prohibited conscious alteration, just as the respect in which the Church Fathers were traditionally held inhibited changes to their works. Saints' lives, on the other hand, allowed a scribe a certain freedom for improvisation and error without immediate repercussions, as long as the scribe respected the spiritual truth of the narrative. ${ }^{61}$ From a spiritual point of view, it mattered little whether Humbertus had blue or grey eyes, whether he led a house for canons or a monastery, or how exactly he tamed the bear that killed his horse, as long

60. Arras, Bibliothèque municipale, MS 723; Gameson, "Signed' Manuscripts," $53-57$.

61. See Monique Goullet, Écriture et réécriture hagiographiques: Essai sur les réécritures de vies de saints dans l'Occident latin médiéval (VIIIeXIIIe s.) (Turnhout, 2005); and La réécriture hagiographique. 
as his sanctity shone through every description and his every deed. ${ }^{62}$ The purpose of a hagiographical narrative was to convey the idea of the saint's sanctity to an audience, rather than inform them about the biographical particulars of his earthly existence. As a result, scribes had always been free to play with hagiographical texts, update them to the requirements of their environments, commit mistakes, and learn how to correct them in a way that was not possible in many other genres. Hagiography was, in other words, a perfect teaching genre.

Secondly, hagiography was easy to read and understand. Contemporaries often repeated that saints' lives were suitable for people who were taking their very first steps on the path of Christian devotion, as the simple stories about saints and their adventures could inspire even the most uncultured monk. ${ }^{63}$ All the monks in Saint-Sépulcre, even the least educated, could thus have worked on this hagiographical codex while understanding what they were writing.

Finally, hagiography was read aloud in front of the entire community during Matins and meal breaks. The large audience gave a hagiographical codex the power to communicate ideas and ideologies to all monks, thereby strengthening their sense of community. In essence, hagiography was aimed at the community rather than the individual. ${ }^{64}$ Contrary to the Saint-Vaast example, the manuscript from Saint-Sépulcre was created by a large part of the mo-

62. "Georgii Florentii Gregorii episcopi Turonensis libri octo Miraculorum," in Gregorii episcopi Turonensis Miracula et opera minora, ed. Bruno Krusch, Monumenta Germaniae historica, Scriptores rerum merovingicarum 1.2 (Hannover, 1885; nov. ed. 1969), 1-370 at 212.

63. William of St.-Thierry, Un traité de la vie solitaire: Epistola ad fratres de Monte-Dei de Guillaume de Saint-Thierry; Édition critique du texte latin, ed. Marie-Madeleine Davy, 2 vols. (Paris, 1940), 1:81, 120-21.

64. Ineke van 't Spijker, "Model Reading: Saints' Lives and Literature of Religious Formation in the Eleventh and Twelfth Centuries," in "Scribere sanctorum gesta": Recueil d'études d'hagiographie médiévale offert à Guy 


\section{Tjamke Snijders}

nastic community-possibly even the entire communityfor the entire community. It was a deliberately simple 40 exercise in which all monks could participate and taste the satisfaction of producing a manuscript together and then listen to their work being read aloud to everyone. The various monks participated at their level of competence. Some were struggling to write at all. Others may have been trying their hands at the selection of texts, whereas the most experienced hands attempted to imitate Fulbert's praescriptio. As such, the monks of Saint-Sépulcre participated each according to his ability.

\section{CONCLUSION}

When Fulbert the Sinner transferred from Normandy to the monastery of Saint-Sépulcre in Cambrai, he arrived in a small, struggling start-up without the means to invest in a scriptorium. Nevertheless, the community needed manuscripts, so Fulbert set to work. The thirteen preserved manuscripts indicate that he wrote more than 1,100 folios of foundational texts: The Monk's Diadem, Cassian's Institutiones and Conferences, Gregory the Great's Commentary in Job. As he could not fill the entire library himself, he enlisted his fellow monks.

Fulbert's habit of signing his manuscripts grants us an unusual glimpse into the organization of this young and relatively insignificant scriptorium. Fulbert was clearly the scribe in charge, who reserved essential texts for himself while leaving the hagiographical codices to others. Some of these other scribes had trained hands, but most were struggling. Fulbert borrowed at least one good hagiographical exemplar from the Cathedral of Cambrai to make the work easier for them. However, he did not ostensibly train the

Phillipart, ed. Étienne Rénard et al., Hagiologia 3 (Turnhout, 2005), 13556 at $144-50$. 
Saint-Sépulcre monks to achieve a recognizable style, with a fixed ductus and a clear layout. Instead, he appears to have allowed these monks to write largely unsupervised, at least when it came to hagiography. The hagiographical codices were suitable for beginners because they were important to the community without containing incomprehensibly abstract reasoning or requiring the scribes to copy their exemplars perfectly.

Fulbert's decision to enlist the monks of Saint-Sépulcre as scribes ensured the rapid and cost-effective creation of the hagiographical codices that were required for the liturgy. His decision had spiritual benefits as well. In the monastic context, writing was seen as a spiritually beneficial act in and of itself: it was entirely equivalent to work or prayer. ${ }^{65}$ As such, the monks' work was not just a pragmatic way of producing more manuscripts: it was a shared spiritual exercise, the fruit of which was read to the entire community during Matins and mealtimes. When the monks were sitting together to listen in reverent silence to the result of their handiwork, the manuscript was more than just the sum of its texts: it was an object that stood for teamwork, unity of purpose, and communality. Cambrai 864 enacted the fellowship of the Saint-Sépulcre monks through a multiplicity of hands and texts. As such, the manuscript was the material apotheosis of this newly founded monastery.

KU Leuven

65. Scribe Rudolph of Saint-Vaast remarks in the eleventh century that every letter, ruled line, and pricking hole that he executed represents a forgiven sin: Arras, Bibliothèque municipale, MS 860, fol. ir (for a transcription, see Gameson, "Signed' Manuscripts," 72). This sentiment is echoed by many, among whom Orderic Vitalis remarked in the early twelfth-century that every letter of "a huge volume of the divine law" (divinae legis) was weighed against the sins of the scribe: Orderic Vitalis, The Ecclesiastical History of Orderic Vitalis, ed. and trans. Marjorie Chibnall, 6 vols. (Oxford, 1969-80), 2:50. 